\title{
INFLUENCE OF CHANGES IN ELECTRICAL AND ELECTRONIC EQUIPMENT ON THE INCREASE OF RELIABILITY IN VEHICLES
}

\section{WPLYW ZMIAN WPROWADZONYCH W WYPOSAŻENIU ELEKTRYCZNYM I ELEKTRONICZNYM NA WZROST NIEZAWODNOŚCI POJAZDÓW}

\author{
Mieczysław Plich ${ }^{1)}$, Mieczysław Dziubiński ${ }^{2)}$, Krzysztof Stypułkowski ${ }^{1 \text { ) }}$ \\ ${ }^{1)}$ Warsaw University of Technology, ${ }^{2)}$ Lublin University of Technology \\ m.plich@wt.pw.edu.pl,m.dziubinski@pollub.pl
}

\begin{abstract}
The article presents considerations for improving the reliability of means of transport after introducing significant structural changes in the installation of vehicles and functioning of the embedded electrical equipment. The consequence of introducing electrical and electronic equipment to vehicles is an increased demand for energy. Uncontrolled consumption of electricity can lead to significant decline in availability. Therefore, the necessity arises of energy management through an additional function of some electrical equipment and implementation of modern design and technology according to the requirements of safety and environmental protection.
\end{abstract}

Keywords: electrical and electronic equipment of vehicles, reliability, environmental protection

Streszczenie: $W$ artykule przedstawiono rozważania dotyczace wzrostu niezawodności środków transportu po wprowadzeniu istotnych zmian strukturalnych $w$ instalacji oraz funkcjonowaniu elektrycznego wyposażenia pojazdów gdzie dodatkowa zaleta powyższych rozwiąań jest wzrost bezpieczeństwa a także obniżenie kosztów eksploatacji. Konsekwencja wzrostu ilości $i$ mocy elementów elektrycznego $i$ elektronicznego wyposażenia pojazdów samochodowych jest zwiększone zapotrzebowanie na energię. Niekontrolowany pobór energii elektrycznej może doprowadzić do znacznego spadku dyspozycyjności. Powstała zatem konieczność zarzadzania energia poprzez ingerencje $w$ funkcje pracy niektórych urządzen wyposażenia elektrycznego a także wdrożenie nowoczesnych rozwiazań technologicznych $i$ konstrukcyjnych spetniajacych wymagania zwiazane takze z bezpieczeństwem i ochrona środowiska naturalnego.

Stowa kluczowe: wyposażenie elektryczne i elektroniczne pojazdów, niezawodność, ochrona środowiska 
Influence of changes in electrical and electronic equipment on the increase...

Wptyw zmian wprowadzonych $w$ wyposażeniu elektrycznym i elektronicznym...

\section{INFLUENCE OF CHANGES IN ELECTRICAL AND ELECTRONIC EQUIPMENT ON THE INCREASE OF RELIABILITY IN VEHICLES}

\section{Introduction}

The consequence of the increase of electrical and electronic equipment elements in vehicles is an enhanced demand for electrical energy. Uncontrolled consumption of electricity may lead to a significant decrease of capacity in all states of vehicle operation.

What can be observed here is a constant gain in the number of electronic devices being components of not only the equipment the aim of which is increasing the comfort of vehicle exploitation, but also of the instruments ensuring active and passive vehicle safety [6].

Taking into account the fact that merely ignition, fuel pump, electronic injection and engine management constitute $300 \div 400 \mathrm{~W}$ of energy, air conditioning and radiator systems additionally constitute $100 \div 500 \mathrm{~W}$, it can be stated that theoretically the demand for energy of an average modern vehicle with a petrol engine depending on the embedded equipment ranges between $400 \div 1600 \mathrm{~W}$ [6]. A vehicle which we would like to additionally equip with safety and driving comfort improving systems would require at least $2 \mathrm{~kW}$ power, and it could be estimated that in the foreseeable future this demand will be within the range of $3.8 \mathrm{~kW}$ for $12 \mathrm{~V}$ installation [6], because it can be assumed that energy consumption will increase in the next years.

In order to avoid excessive stationary discharge of a source which in the case of vehicles is a car battery, and to ensure the required capability of vehicle engine run-up, the need arose for introduction of energy management system.

Currently, vehicles require more and more reliable and intelligent electrical energy supply systems. Even today such trademarks as Mercedes - Benz or VW group propose energy management system controllers for their vehicles in order to distribute power produced by alternator to particular receivers in a rational and economical way [3].

An example of such a controller can be the one used by a VW group. This device closely cooperates with CAN and LIN buses, through which it controls battery charging voltage and determines its general technical state. This controller also coordinates alternator operation through managing combustion engine speed and adjusting the time of increasing its load. The controller also actively participates in monitoring the quality of electrical energy through controlling voltage regulator operation. Moreover, it supervises the functioning of particular receivers, that is disconnection of redundant branches of the system after switching off power supply, and also reducing the scope of work of receivers when they are supplied with power, for instance electric coolant pumps, air conditioning systems, or electronic thermostats actively regulating engine operation temperature. 
The necessity has therefore arisen to economise on energy through interference into the substance of operation of certain devices of electrical equipment, and to implement modern technological and construction solutions meeting particular requirements also connected with safety and environmental protection.

Thanks to the implementation of such a device as a dual generator/starter, quiet and fast engine run-up has become possible in the start-stop mode during vehicle movement in urban traffic. Moreover, dual generator/starters are to ensure reduced exhaust pipe emissions and fuel consumption, as well as decreasing the level of vibrations and noise emission and additional support for the engine torque for the purpose of easier moving off (the so called Booster).

Furthermore, it turns out that a series of other possibilities exist which allow for processing and gathering vehicle kinetic energy. The change of kinetic energy into electrical energy and then gathering it in appropriate storage, that is in supercapacitors or in batteries. This solution seems the most promising despite having significant limitations [8].

Another change in electrical equipment of vehicles is the implementation of new construction solutions for motor car lights with LED source lights, which substituted traditional sources and allowed for controlling luminous intensity and ensured additional light effects.

In accordance with the regulations binding as of 17 April 2007, all vehicles moving on public roads in Poland must have low beam lights on when driving in daytime all year round. Therefore, thanks to LED technology, a new type of lighting has been implemented under the notion of daytime running lights being a different vehicle lighting from traditional low beam lights. Daytime running lights which switch on automatically on starting the vehicle, apart from improving vehicle visibility, emit sharp but not blinding light which is visible well on a sunny day, consuming even $90 \%$ less power than typical low beam lights [9].

\section{Energy Management Systems}

The computer controlling energy management system performs constant monitoring of the state of battery charging and its capability of run-up, as well as regulation of alternator charging voltage. This computer can control the load, the number of idle speed rotations and the decrease of quiescent current with a switched off engine, where in an extreme case it can disconnect particular receivers by means of CAN bus.

The controlling computer by supervising the battery voltage manages the demand for current of particular receivers that are switched on for a short period of time. Figure 1 presents an equivalent computer circuit with elements and receivers that are covered by the management system. [14]. 
Influence of changes in electrical and electronic equipment on the increase... Wptyw zmian wprowadzonych $w$ wyposażeniu elektrycznym i elektronicznym...

The tasks of the controlling computer consist in three ranges of activity, namely [3]:

- battery management system and its diagnosis (always active),

- quiescent current management system, which, when the need arises, disconnects the receivers operating during the vehicle parking (when the engine is not working),

- dynamic management system regulating the charging voltage and the decrease in the number of switched on receivers (during the engine operation).

In order to conduct the battery diagnosis, the energy management system in the controlling computer must estimate the following data concerning the battery temperature, its voltage and current as well as operation time.

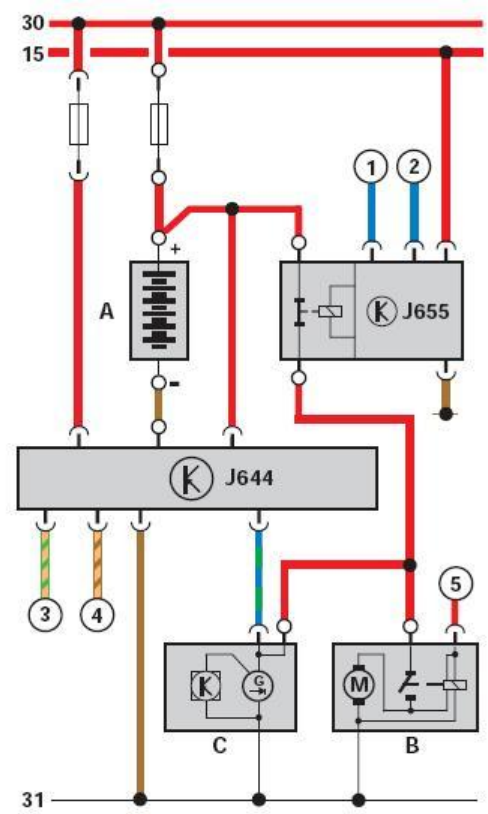

Fig. 1. Circuit diagram of controlling computer cooperation with receivers [14]. A battery, B starter, $C$ alternator, J644 computer controlling energy management, J655 battery disconnect relay. Additional signals: 1 and 2 computers controlling the airbag J234, 3 and 4 Komfort system data buses (high, low), 5 terminal 50 (from relay 2 of starter J695)

The task of the quiescent current management system in the controlling computer J644 is the request, when the need arises, to disconnect the receivers through the cooperating controlling computers, which is realized at six degrees. Establishing the levels of disconnection occurs consecutively 1-2-5-3-6, which has been illustrated in a graphic form in figure 2 . The lower the state of battery charging, the higher the level of disconnection. 
The necessary level of disconnection is regulated by data buses systems by means of the computer controlling the system of energy management, of which the driver is being informed via a set of indicators.

The main tasks of the dynamic management system are the following: regulation of battery voltage, runback, regulation of high power heating systems, increasing the rotation of idle gear, switching on the alternator and regulation of its voltage.

The computer J644 controlling the energy management system transmits data of the required voltage to the alternator, which becomes regulated by the alternator. The car battery management system determines the required value on the basis of battery temperature and its state of charging. The determined required value is then transmitted to the dynamic management system, which further transmits it to the alternator.

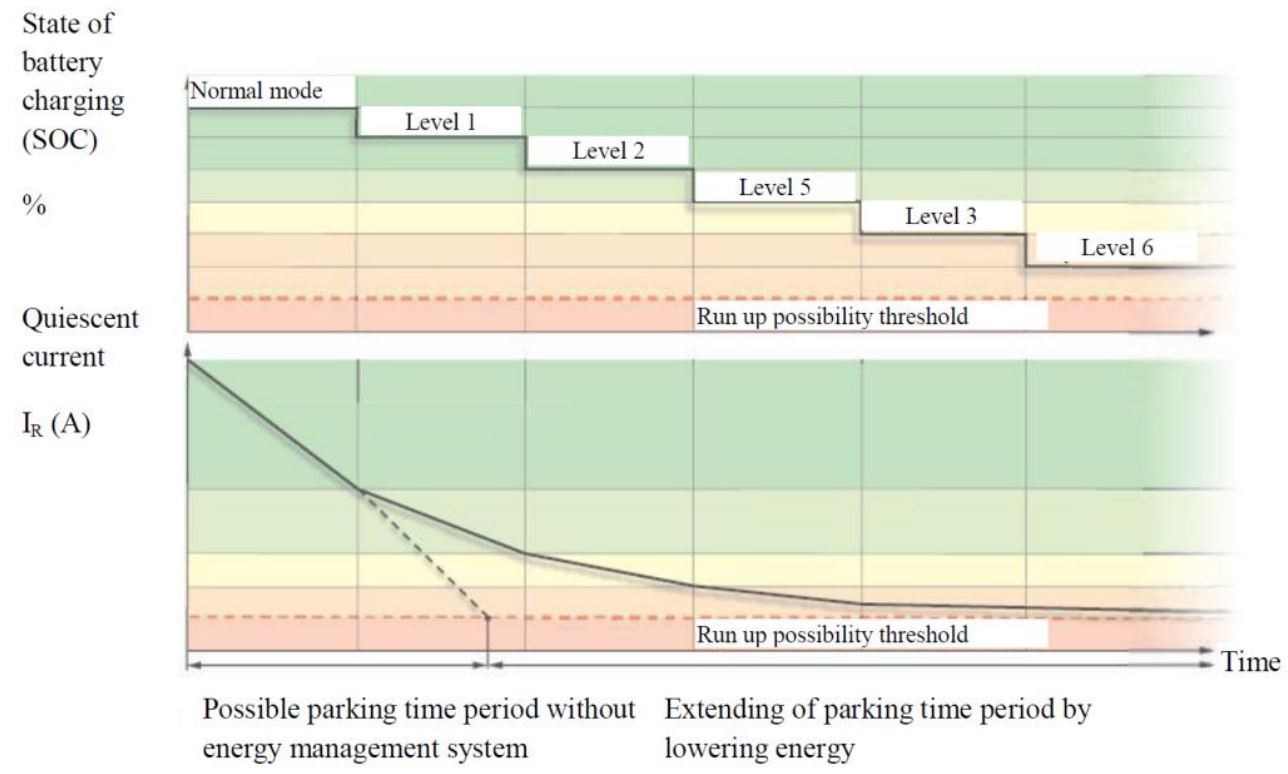

Fig. 2. Maintenance of energy management readiness [14]

The abovementioned disconnections cause the following effects for the levels:

- 1 and 2 - disconnection of receivers of Komfort system data bus,

- 3 - quiescent current reduction is introduced,

- 5 - parking heating is deactivated,

- 6 - further restrictions for data buses systems.

The controlling computer can also decrease the engine load e.g. during the changes of acceleration on request of the computer controlling the engine. If this computer requests the decrease of load, the energy management system limits energy consumption by the receivers of high power on the first level, and on the second level - the alternator voltage - in order to decrease power consumed by the alternator. 
Influence of changes in electrical and electronic equipment on the increase... Wptyw zmian wprowadzonych $w$ wyposażeniu elektrycznym i elektronicznym...

Moreover, the controlling computer sends a request to the computer $\mathrm{J} 255$ by means of CAN bus of Komfort system controlling the Climatronic system, which regulates different heating systems, such as heated windscreen, heated seats, heated rear window and additional PTC.

For the optimal network power supply and battery charging, the energy management system may request an increase of the number of rotations of an idle gear from the computer controlling the engine. Furthermore, during the engine start-up, power consumption by the alternator becomes minimized in order to optimize the cold start of a combustion engine.

\section{Dual generator/starter and start-stop operation mode}

The construction which seems to satisfy the power needs of a vehicle in the long run is a dual generator/starter e.g. ISAD type, where management systems have been integrated in one intelligent control unit. Moreover, the range of control functions has been extended and improved in relation to the systems with alternators and starters installed separately.

Examples of various construction solutions of these devices have been presented in figure 3 .
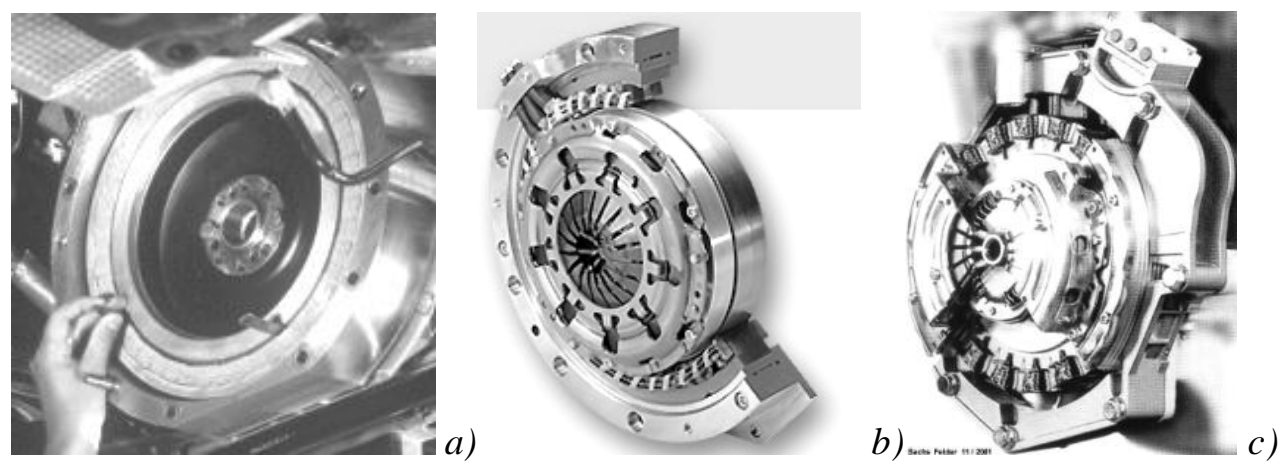

Fig. 3. Dual generator/starters for vehicles in different construction variants:

a) ISAD (Integrated Starter Alternator Damper) by Continental, b) FSA (Flywheel Starter Alternator) by Bosch,

c) CSG (Crankshaft Starter Generator) by Mannesmann-Sachs. [12]

This type of machine from the point of view of key parameters, such as efficiency and power, surpasses the conventional solutions, fulfilling simultaneously growing environmental demands concerning the level of noise, vibrations and exhaust pipe emissions. Application of the start-stop function ensures reducing fuel consumption by about 5\% [12], and when linked with brake energy recuperation system - even by $11 \%$. The Booster function is not insignificant either, which improves the vehicle dynamics. These devices are also equipped with the function of electric power supply of the levels of $110 \mathrm{~V}$ or $220 \mathrm{~V}$ for external reception. 


\section{Other changes in electrical equipment of vehicles}

Apart from the changes in electrical equipment of vehicles enumerated in previous chapters of the present paper, there is a series of various other solutions, some of which have been described below.

It is common knowledge that a vehicle braking process is a significant source of energy losses, therefore, it is indispensable to apply additional devices which will allow for transmitting and storing recuperated energy [10]. The characteristics of a combustion engine indicate that about $1 / 3$ of energy contained in the fuel is directly used for creating work effective for vehicle drive and other receivers. The rest, that is, about $2 / 3$ of energy „escapes" from the engine in the form of heat created by the engine. A possible solution of the problem can be the application of a thermo-generator installed on an exhaust pipe which changes heat into electric energy, which in turn can allow for reducing fuel consumption by about 5\% [3].

Another way of reducing energy losses is recuperating it from braking process, where, for instance, in hybrid vehicles it is possible to recharge the batteries when driving, which in effect reduces fuel consumption as well as emission of substances polluting the natural environment.

Figure 4 presents the way of the use of energy in a hybrid vehicle on the example of a Toyota vehicle.

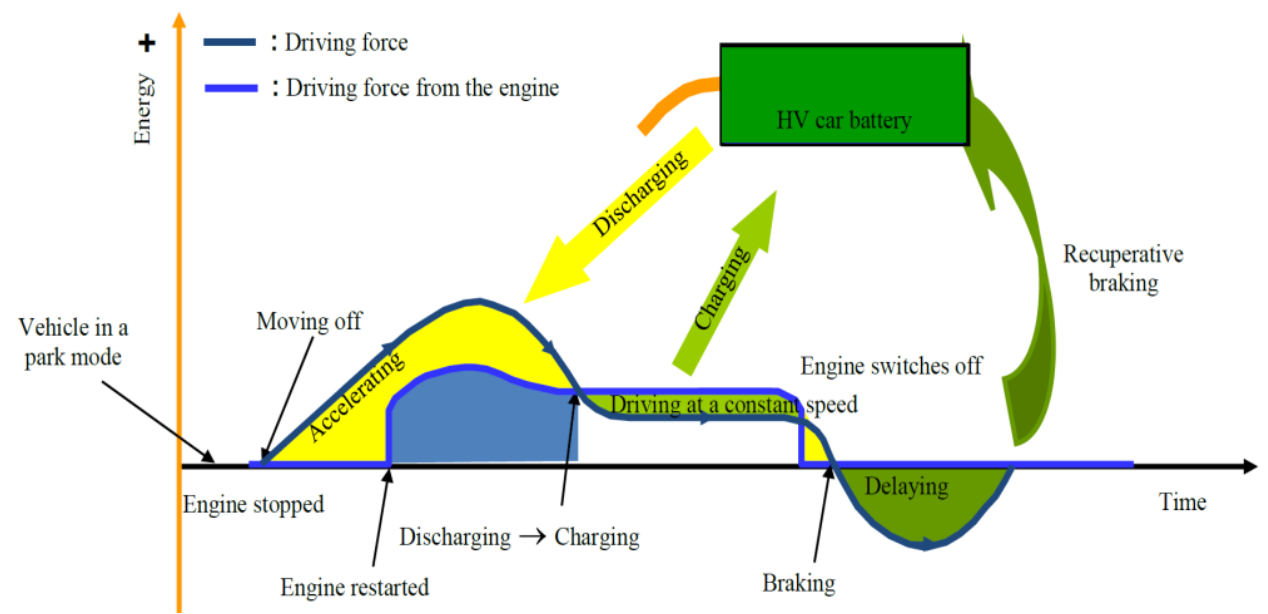

Fig. 4. The way of energy use in a hybrid vehicle [2]

The justification for the use of a hybrid drive is urban traffic in which frequent braking, stops at crossroads and driving in traffic jams allow for recuperating kinetic energy of the movement and optimal use of combustion engine power. Such a solution gives the possibility of a very high level of energy saving reaching even up to about $50 \%$ [10]. 
Influence of changes in electrical and electronic equipment on the increase... Wptyw zmian wprowadzonych $w$ wyposażeniu elektrycznym i elektronicznym...

In the type of vehicles in which a combustion engine cooperates with an electric engine with electronically controlled braking system (ECB), the brake force is distributed between the hydraulic brake system and recuperative braking, which has been presented in a graphic form in figure 5. This distribution depends on speed and vehicle driving time.

The solution of the problem of electrical energy recuperation based on the use of alternator and supercapacitor was proposed by Mazda concern in i-ELOOP system. The process of energy production and charging of a supercapacitor occurs after releasing the accelerator pedal in a car whose speed is dropping. The recuperated energy may serve for supplying peripheral devices of a vehicle, such as air conditioning or audio system. According to the producer's assurances, the i-ELOOP system allows for fuel saving by even $10 \%$ [5].

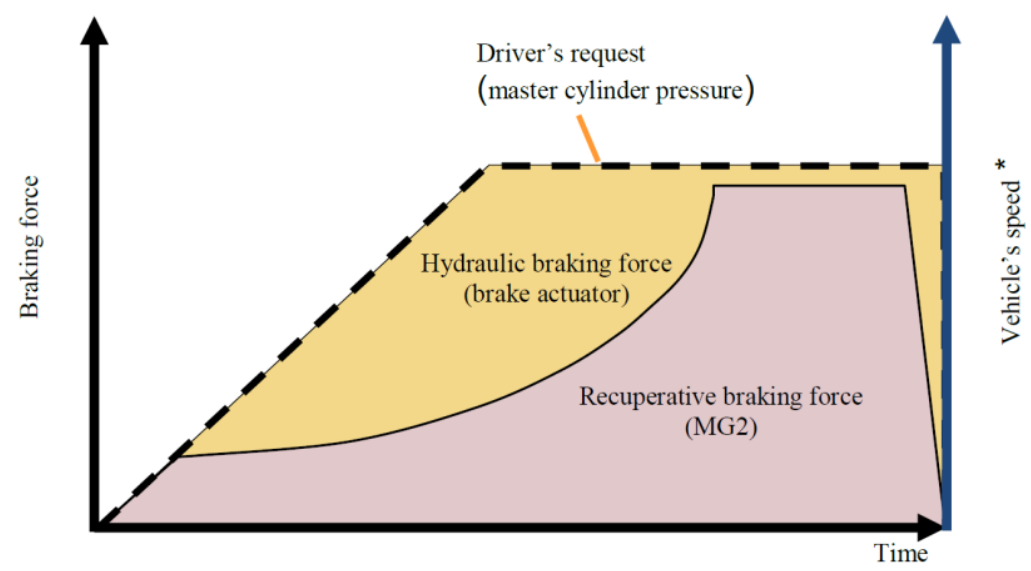

Fig. 5. Changes in the distribution of the braking force within (ECB) system [2]

Traditional lead-acid batteries lack the possibility of absorbing high currents during vehicle's braking without a significant reduction of their lifecycle, supercapacitors, however, are able to absorb and distribute currents of the value of up to $800 \mathrm{~A}$ without durability loss. Supercapacitors are applicable where there is a need for high power outfeed in a short period of time and fast storage of large amounts of energy at the flow of high value currents [1].

Another energy saving system is based on the fact that kinetic energy of the flowing exhaust pipe fumes is used for driving a turbo generator located in the exhaust system of a combustion engine. The task of a high rotation generator is to support the work of an alternator and improve energy balance of the power supply system [5]. This turbo generator cooperating with the engine of ZI ignition and capacity of $2000 \mathrm{dm}^{3}$ is able to generate power of the maximum value even of $6 \mathrm{~kW}[6]$. 
Such a solution can be applied in hybrid vehicles as a component improving electrical energy balance cooperating with devices recuperating energy from kinetic force, which influences the reliability of this system.

Analysing the energy balance of the lighting circuit, it can be stated that switching on the low beam lights is connected with power consumption of the value of about $130 \mathrm{~W}$. Currently, regulations allow switching on only daytime running lights (without front and rear position lights and number plate lights). Application of two lights with LED lamps of the power of about $5 \mathrm{~W}$ means a complete consumption of power at the level of $10 \mathrm{~W}$. In effect, fuel consumption is lower by even $0.2 \mathrm{l} / 100 \mathrm{~km}$, which multiplied by the number of vehicles on roads means reduction of carbon dioxide emission into atmosphere [13].

Conventional light sources have been substituted with LED lamps also in signal light circuits of the following lights: parking lights, position lights and indicators obtaining energy savings, increase of reliability and additionally the possibility of controlling brightness of braking lights depending on their intensity.

Currently, the sources of LED type of light are used more and more frequently in lighting technology because of much longer durability and energy saving in comparison with traditional sources. The same lighting function is realized with a much lower power consumption, for example, a position light with a light bulb of the power of $10 \mathrm{~W}$ can be made with the use of LED of the power of $1 \mathrm{~W}$ [4]. What is of great significance, considering the driver's reaction time, is a much shorter time of achieving a full light beam immediately after switching on power supply, which can for instance influence the reduction of a braking distance due to a faster reaction of users observing these lights. The most important regulation in the European Union concerning daytime running lights is ECE Regulation 87 [9]. Certain producers of motor vehicles take into consideration the use of solar energy for power supply of particular devices of the comfort system. In these solutions the efficiency of solar energy conversion is achieved with $15 \%$ per $1 \mathrm{~m}^{2}$ of surface and thermal insulation equalling $500 \mathrm{~W} / \mathrm{m}^{2}[3]$.

\section{Summary and Conclusions}

The paper presents considerations concerning the growth of vehicle's reliability as a result of introducing significant structural changes in the installation and functioning of electrical equipment. In connection with the increase of the number of elements and subassemblies of high power consumption and the appearance of hybrid and electric drives, the demand for electric energy has increased.

As a result of the above, electric power supply circuit must meet new requirements also referring to reliability, therefore, energy management system has been implemented, where by means of a controlling computer, an active diagnosis of the battery and load control is carried out in order to guarantee sufficient energy for a combustion engine run-up. 
Influence of changes in electrical and electronic equipment on the increase... Wptyw zmian wprowadzonych $w$ wyposażeniu elektrycznym i elektronicznym...

Integrated system of power supply and engine run-up realized in one electric machine of dual generator/starter combines two functions of power supply and run-up, which influences a significant increase of reliability of this system, and work in start-stop mode especially in urban traffic may ensure reduction of fuel consumption even by $20 \%$. This gives an important ecological aspect in the form of reduction of exhaust pipe fumes emission, and fast and quiet engine run-up, as well as safety increase and lowering exploitation costs.

A noteworthy feature of modern electric vehicles' drives is the possibility of energy recuperation during braking where the efficiency of recuperation is substantially dependent on the drive system configuration. Comprehensive implementation of recuperative braking should be expected, because new possibilities of accumulating electric energy in supercapacitors increases its efficiency. This change of the way of driving vehicles leads to substantial energy consumption savings, particularly in the case of driving in urban traffic where these savings can reach even up to $50 \%$.

Application of LED sources of light in daytime running lights is also connected with a significant improvement of reliability and safety, because lighting of this type is characterised by long lifespan, shock resistance, low power consumption, emitting sharp and clear light which is well visible in daytime.

\section{References}

[1] Fice M. Setlak R.: Napęd hybrydowy pojazdów miejskich z podwójnym zasobnikiem energii elektrycznej. Zeszyty Problemowe - Maszyny elektryczne Nr 79/2008, 138-144.

[2] Grudziński P.: System napędu hybrydowego Toyota. Akademia Toyoty Toyota Motor Poland.

[3] Herner A. Riehl H-J.: Elektrotechnika i elektronika w pojazdach samochodowych, WKŁ, Warszawa 2014.

[4] Kaźmierczak P.: Źródła LED w samochodowej technice świetlnej, Transport Samochodowy 2011, nr 4, 85-94.

[5] Luft M. Olszowiec P.: Analiza systemów podnoszących sprawność silników spalinowych, Logistyka 2012, nr 3, 1389-1393.

[6] Luft M. Olszowiec P.: Straty silnika spalinowego szansą na rekuperację energii elektrycznej, Logistyka 2011, nr 6, 2291-2299.

[7] Merkisz J. Pielecha I.: Układy elektryczne pojazdów hybrydowych, WPP, Poznań 2015,.

[8] Plich M.: Alternatywne źródła zasilania energią pojazdów samochodowych. Międzynarodowa Konferencja Naukowa Transport XXI Wieku. Warszawa 2004.

[9] Putz Ł.: Oświetlenie LED jako samochodowe światła do jazdy dziennej, Poznań University Of Technology Academic Journals, Electrical Engineering, No 83/2015, 221-228. 
[10] Sosin Z.: Niekonwencjonalne napędzanie samochodów - sposób na obniżenie kosztów transportu i zmniejszenie zanieczyszczenia środowiska. Foton 102, Jesień 2008.

[11] Tutaj J.: Nowe rozwiązanie samochodowego prądnico-rozrusznika, Journal of KONES Internal Combustion Engines 2005, vol. 12, 335-342.

[12] www.creeaza.com/tehnologie/electronica-electricitate/Masina-electricaspeciala-cu-r983.php (dostęp z dnia 15.10.2015).

[13] www.motofakty.pl/artykul/dzial-oswietlenie-diodowe-swiatla-do-jazdydziennej.html (dostęp z dnia 15.09.2015).

[14] Zeszyt do samodzielnego kształcenia nr 287, Audi A8' 03 - podzespoły elektryczne.

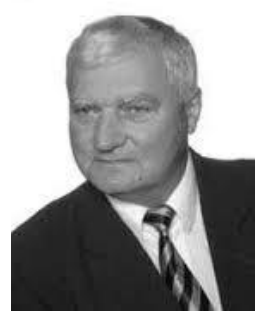

Mieczystaw Plich, PhD Eng. works at the Department of Information Technology and Mechatronics in Transport of the Faculty of Transport of Warsaw University of Technology. In his research work he mainly deals with subjects connected with electrical equipment of motor vehicles. (Share 34\%).

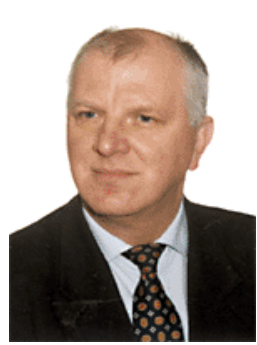

Mieczystaw Dziubiński, PhD Eng. works at the Department of Automotive Vehicles of the Faculty of Mechanical Engineering of Lublin University of Technology. In his research work he deals with diagnostics, electrical engineering and automotive electronics. (Share 33\%).

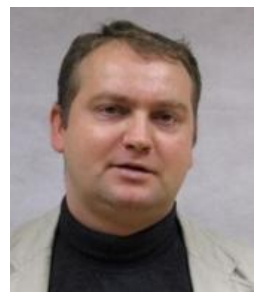

Krzysztof Stypulkowski, PhD Eng. works at the Department of Information Technology and Mechatronics in Transport of the Faculty of Transport of Warsaw University of Technology. In his research work he mainly deals with subjects connected with electrical equipment of vehicles, lighting technology and thermovision in transport. (Share 33\%). 
Influence of changes in electrical and electronic equipment on the increase... Wptyw zmian wprowadzonych $w$ wyposażeniu elektrycznym i elektronicznym...

\section{WPLYW ZMIAN WPROWADZONYCH W WYPOSAŻENIU ELEKTRYCZNYM I ELEKTRONICZNYM NA WZROST NIEZAWODNOŚCI POJAZDOW}

\section{Wstęp}

Konsekwencją wzrostu elementów elektrycznego i elektronicznego wyposażenia pojazdów samochodowych jest zwiększone zapotrzebowanie na energię elektryczną. Niekontrolowany pobór energii elektrycznej może doprowadzić we wszystkich stanach pracy samochodu do znacznego spadku dyspozycyjności.

Obserwujemy tu ciągły przyrost ilości urządzeń elektronicznych będących częścią składową nie tylko wyposażenia mającego na celu podniesienie komfortu eksploatacji pojazdu, lecz także instrumentów zapewniających bezpieczeństwo czynne i bierne samochodu [6].

Biorąc pod uwagę to, że zaledwie zapłon, pompa paliwa, elektroniczny wtrysk i zarządzanie silnikiem to $300 \div 400 \mathrm{~W}$ energii oraz klimatyzacja $\mathrm{i}$ układy chłodzenia dodatkowo $100 \div 500 \mathrm{~W}$ można stwierdzić, że teoretyczne zapotrzebowanie przeciętnego współczesnego pojazdu z silnikiem benzynowym w zależności od wyposażenia zawiera się w przedziale $400 \div 1600 \mathrm{~W}$ [6].

Samochód który ponad to chcielibyśmy wyposażyć dodatkowo w układy poprawiające bezpieczeństwo i komfort jazdy to wymagane byłoby już co najmniej $2 \mathrm{~kW}$ mocy, a można szacować że w następnych latach będzie to już poziom $3,8 \mathrm{~kW}$ dla instalacji $12 \mathrm{~V}$ [6] ponieważ można założyć, że w kolejnych latach wzrośnie konsumpcja energii.

W celu uniknięcia nadmiernego wyładowania stacjonarnego źródła jakim jest w pojazdach samochodowych akumulator i zapewnienia wymaganej zdolności do rozruchu silnika zaistniała potrzeba wdrożenia układu zarządzania energią.

Obecnie pojazdy wymagają coraz bardziej niezawodnych i inteligentnych układów zasilania w energię elektryczną. Już dziś takie marki jak Mercedes - Benz czy grupa VW proponują do swoich pojazdów kontrolery zarządzania energią by racjonalnie i ekonomicznie dystrybuować wytworzoną przez alternator moc do poszczególnych odbiorników [3].

Przykładem takiego sterownika jest kontroler stosowany przez grupę VW. Urządzenie to ściśle współpracuje z magistralą CAN oraz LIN przez co nadzoruje stan naładowania akumulatora oraz określa jego ogólny stan techniczny. Sterownik ten koordynuje także prace alternatora poprzez zarządzanie obrotami silnika spalinowego oraz dopasowaniem czasu zwiększenia jego obciążenia. Kontroler ten bierze także czynny udział w nadzorowaniu jakością energii elektrycznej poprzez kontrolę pracy regulatora napięcia. Ponadto sprawuje on nadzór nad funkcjonowaniem poszczególnych odbiorników, a wiec wyłączaniem zbędnych gałęzi układu po wyłączeniu zasilania a także redukcję zakresu pracy odbiorników w czasie ich zasilania jak np. elektryczne pompy płynu chłodniczego, układy klimatyzacji czy też elektroniczne termostaty czynnie regulujące temperaturę pracy silnika. 
Powstała zatem konieczność oszczędzania energii poprzez ingerencję w istotę działania niektórych urządzeń wyposażenia elektrycznego a także wdrożenie nowoczesnych rozwiązań technologicznych i konstrukcyjnych spełniających określone wymagania związane również z bezpieczeństwem i ochroną środowiska naturalnego.

Dzięki wdrożeniu takiego urządzenia jak prądnico-rozrusznik stało się możliwe ciche i szybkie uruchamianie silnika $\mathrm{w}$ trybie start-stop podczas jazdy w ruchu miejskim. Ponadto prądnico-rozruszniki mają zapewnić zmniejszoną emisję spalin i zużycie paliwa oraz obniżenie poziomu drgań i emisji hałasu a także dodatkowe wsparcie dla momentu obrotowego silnika celem łatwiejszego ruszania $\mathrm{z}$ miejsca (tzw. Booster).

Okazuje się ponadto, że istnieje szereg innych możliwości pozwalających na przetwarzanie i gromadzenie energii ruchu samochodu. Zamiana energii kinetycznej na energię elektryczną, a następnie gromadzenie jej w odpowiednich zasobnikach czyli w superkondensatorach albo akumulatorach. Rozwiązanie to wydaje się najbardziej obiecujące, choć posiada ono swoje istotne ograniczenia [8]. Kolejna zmiana w wyposażeniu elektrycznym pojazdów samochodowych to wdrożenie nowych rozwiązań konstrukcyjnych lamp samochodowych ze źródłami światła typu LED, które zastąpiły tradycyjne źródła i umożliwiły sterowanie zmiennością światłości oraz zapewniły dodatkowe efekty świetlne.

Zgodnie z obowiązującymi przepisami od 17 kwietnia 2007 roku wszystkie pojazdy poruszające się po drogach publicznych w Polsce muszą mieć włączone światła mijania w ciągu dnia, o każdej porze roku, dlatego dzięki technologii LED wdrożono nowy typ oświetlenia wprowadzają pojęcie świateł do jazdy dziennej, będących odmiennym oświetleniem pojazdu niż tradycyjne światła mijania. Światła do jazdy dziennej, które włączają się automatycznie po uruchomieniu pojazdu poza poprawą widoczności pojazdu, emitują ostre, ale nieolśniewające światło, dobrze widoczne w słoneczny dzień, pobierając przy tym nawet o $90 \%$ mniej mocy niż typowe światła mijania [9].

\section{Układy zarządzania energią}

Za pomocą komputera sterującego układem zarządzania energią realizowana jest ciągła kontrola stanu naładowania akumulatora i jego zdolności rozruchowej a także regulacja napięcia ładowania alternatora. Komputer ten może sterować obciążeniem, liczbą obrotów biegu jałowego i zmniejszeniem prądu spoczynkowego przy wyłączonym silniku, gdzie w przypadku ekstremalnym może on także za pomocą magistrali CAN odłączać poszczególne odbiorniki.

Komputer sterujący nadzorując napięcie akumulatora zarządza zapotrzebowaniem na prąd poszczególnych odbiorników włączanych na krótki okres czasu. $\mathrm{Na}$ rysunku 1 przedstawiono schemat zastępczy komputera $\mathrm{z}$ elementami i odbiornikami objętymi zarządzaniem [14]. 
Influence of changes in electrical and electronic equipment on the increase... Wptyw zmian wprowadzonych $w$ wyposażeniu elektrycznym i elektronicznym...

Zadania komputera sterującego sprowadzają się do trzech zakresów działań a mianowicie [3]:

- układ zarządzania akumulatorem i jego diagnozy (zawsze aktywny),

- układ zarządzania prądem spoczynkowym, który w razie potrzeby odłącza odbiorniki działające w czasie postoju samochodu (gdy silnik nie pracuje),

- dynamiczny układ zarządzania regulujący napięcie ładowania i zmniejszenie ilości włączonych odbiorników (podczas pracy silnika).

W celu przeprowadzenia diagnozy akumulatora, układ zarządzania energią w komputerze sterującym musi ustalić następujące dane dotyczące: temperatury akumulatora, jego napięcia i natężenia prądu oraz czasu pracy.

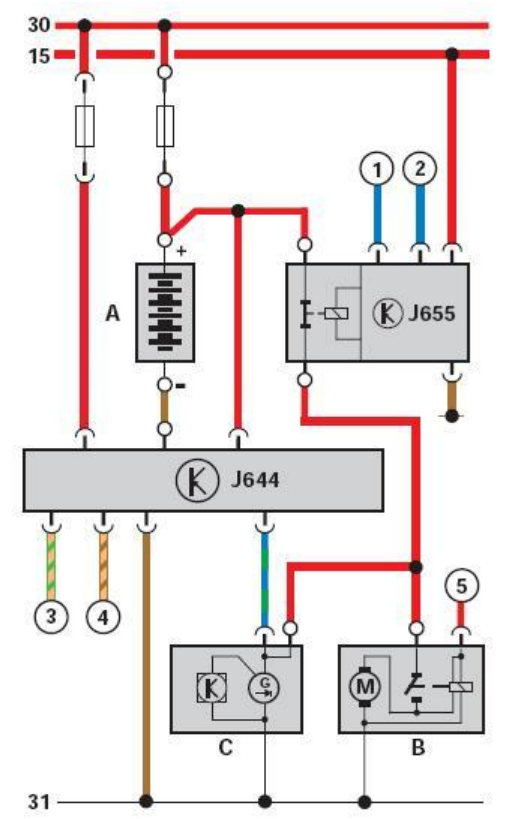

Rys. 1. Schemat wspótpracy komputera sterujacego z odbiornikami [14] A akumulator, B rozrusznik, C alternator, J644 komputer sterujacy systemem zarzadzania energia, J655 przekaźnik odtaczania akumulatora. Sygnały dodatkowe: 1 i 2 komputery sterujacy poduszka bezpieczeństwa J234, 3 i 4 magistrale danych systemu Komfort (high, low), 5 zacisk 50 (od przekaźnika 2 rozrusznika J695)

Zadaniem układu zarządzania prądem spoczynkowym w komputerze sterującym J644 jest żądanie, w razie potrzeby, odłączenia odbiorników poprzez współpracujące komputery sterujące, które realizowane jest w sześciu stopniach. Ustalenie poziomów odłączania następuje kolejno 1-2-5-3-6 co zilustrowano graficznie na rysunku 2. Im mniejszy jest stan naładowania akumulatora, tym wyższy jest poziom odłączenia. 
Konieczny poziom odłączenia jest nastawiany przez systemy magistrali danych poprzez komputer sterujący układem zarządzania energią o czym kierowca informowany jest za pośrednictwem zestawu wskaźników.

Główne zadania dynamicznego układu zarządzania to: regulacja napięcia akumulatora, odciążenia, regulacja układów grzania o dużej mocy, podwyższanie obrotów biegu jałowego, włączanie alternatora oraz regulacji jego napięcia.

Komputer J644 sterujący układem zarządzania energią przekazuje do alternatora dane o wymaganym napięciu, które zostaje wyregulowane przez alternator. Układ zarządzania akumulatorem określa wymaganą wartość na podstawie temperatury akumulatora i jego stanu naładowania. Ustalona wymagana wartość przekazana zostaje następnie do dynamicznego układu zarządzania, który przekazuje ją dalej do alternatora.

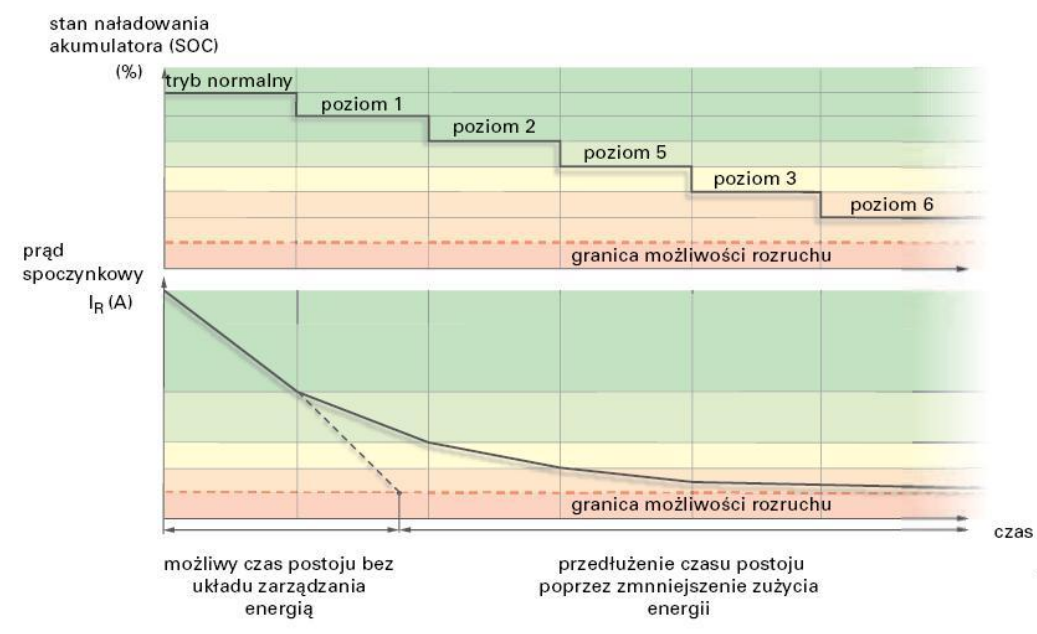

Rys. 2. Utrzymanie gotowości zarządzania energia [14]

Wyżej wymienione odłączenia powodują następujące skutki dla poziomów:

- 1 i 2 wyłączanie odbiorników magistrali danych systemu Komfort,

- 3 wprowadzone zostaje ograniczenie prądu spoczynkowego,

- 5 ogrzewanie postojowe zostaje dezaktywowane,

- 6 dalsze ograniczania dla systemów magistral danych.

Komputer sterujący może także zmniejszyć obciążenie silnika np. podczas zmian przyspieszania, na żądanie komputera sterującego silnikiem. Jeżeli komputer ten zażąda zmniejszenie obciążenia, układ zarządzania energią ograniczy na pierwszym poziomie pobór energii przez odbiorniki dużej mocy, a na drugim poziomie napięcie alternatora $\mathrm{w}$ celu zmniejszenia mocy, którą pobiera alternator. Ponadto komputer sterujący wysyła poprzez magistralę CAN systemu Komfort żądanie do komputera J255 sterując układem Climatronic, który reguluje różne układy ogrzewania, jak np. ogrzewanie przedniej szyby, siedzeń, tylnej szyby i dodatkowe PTC. 
Influence of changes in electrical and electronic equipment on the increase... Wplyw zmian wprowadzonych $w$ wyposazeniu elektrycznym i elektronicznym...

W celu optymalnego zasilania sieci w energię i ładowania akumulatorów, układ zarządzania energią może zażądać od komputera sterującego silnikiem wzrostu liczby obrotów biegu jałowego. Poza tym podczas uruchamiania silnika pobór mocy alternatora zostaje zminimalizowany $\mathrm{w}$ celu zoptymalizowania rozruchu zimnego silnika spalinowego.

\section{Prądnico - rozrusznik i tryb pracy start-stop}

Konstrukcją, która wydaje się zaspokajać potrzeby energetyczne pojazdu w szerszej perspektywie czasowej, jest prądnico - rozrusznik np. typu ISAD gdzie zintegrowano układy zarządzania, w jeden zespół inteligentnego sterowania. Ponadto zakres funkcji sterujących został rozszerzony i poprawiony, w stosunku do układów z alternatorem i rozrusznikiem montowanymi oddzielnie.

Przykłady różnych rozwiązań konstrukcyjnych tych urządzeń przedstawiono na rysunku 3.
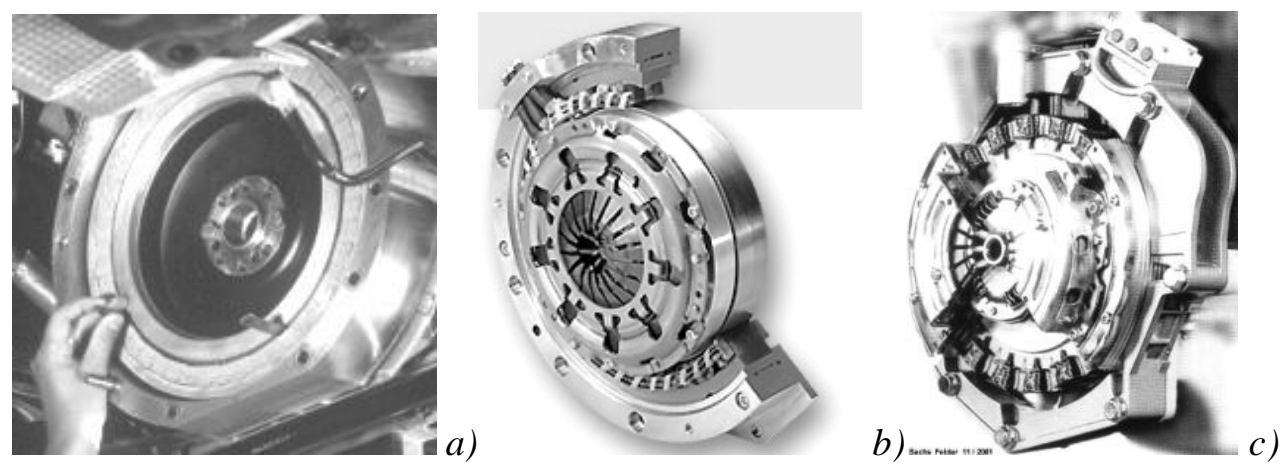

Rys. 3. Prądnico-rozruszniki samochodowe w różnych wariantach konstrukcyjnych: a) ISAD (Integrated Starter Alternator Damper) firmy Continental, b) FSA (Flywheel Starter Alternator) firmy Bosch,

c) CSG (Crankshaft Starter Generator) firmy Mannesmann-Sachs. [12]

Maszyna tego typu pod względem kluczowych parametrów takich jak sprawność i moc przewyższa rozwiązania konwencjonalne, spełniając również rosnące wymagania środowiskowe dotyczące poziomu hałasu, drgań i emisji spalin. Zastosowanie funkcji start-stop zapewnia mniejsze zużycie paliwa o około 5\% [12], a w połączeniu $\mathrm{z}$ systemem odzyskiwania energii hamowania nawet o około $11 \%$. Nie bez znaczenia jest również funkcja Booster, która poprawia dynamikę pojazdu. Urządzenia te posiadają również funkcję dostarczania energii elektrycznej o poziomach $110 \mathrm{~V}$ lub $220 \mathrm{~V}$ dla odbiorów zewnętrznych. 


\section{Pozostałe zmiany w wyposażeniu elektrycznym pojazdów}

Poza wymienionymi w poprzednich rozdziałach niniejszego opracowania mianami w wyposażeniu elektrycznym pojazdów istnieje szereg innych rozwiązań z których kilka wybranych opisano poniżej.

Wiadomo że proces hamowania samochodu to znaczące źródło strat energii, dlatego niezbędne jest zastosowanie dodatkowych urządzeń, które pozwola na przekazanie i zmagazynowanie odzyskanej energii [10]. Charakterystyka silnika spalinowego sprawia, że tylko około $1 / 3$ energii zawartej w paliwie jest zużywana bezpośrednio do wytworzenia pracy efektywnej do napędu pojazdu i innych odbiorników. Reszta, czyli około $2 / 3$ energii „uchodzi” z silnika pod postacią ciepła wytwarzanego przez silnik. Rozwiązaniem tego problemu może być zastosowanie termogeneratora, który montowany na rurze wydechowej zamienia ciepło na energię elektryczną co pozwala obniżyć zużycie paliwa o około 5\% [3].

Kolejnym sposobem ograniczającym straty energii jest odzyskiwanie jej z procesu hamowania, gdzie np. w pojazdach hybrydowych możliwe jest podczas hamowania ładowanie akumulatorów co daje w efekcie zmniejszenie zużycia paliwa a także emisji szkodliwych dla środowiska naturalnego substancji.

$\mathrm{Na}$ rysunku 4 zaprezentowano sposób wykorzystania energii w pojeździe hybrydowym na przykładzie samochodu Toyota.

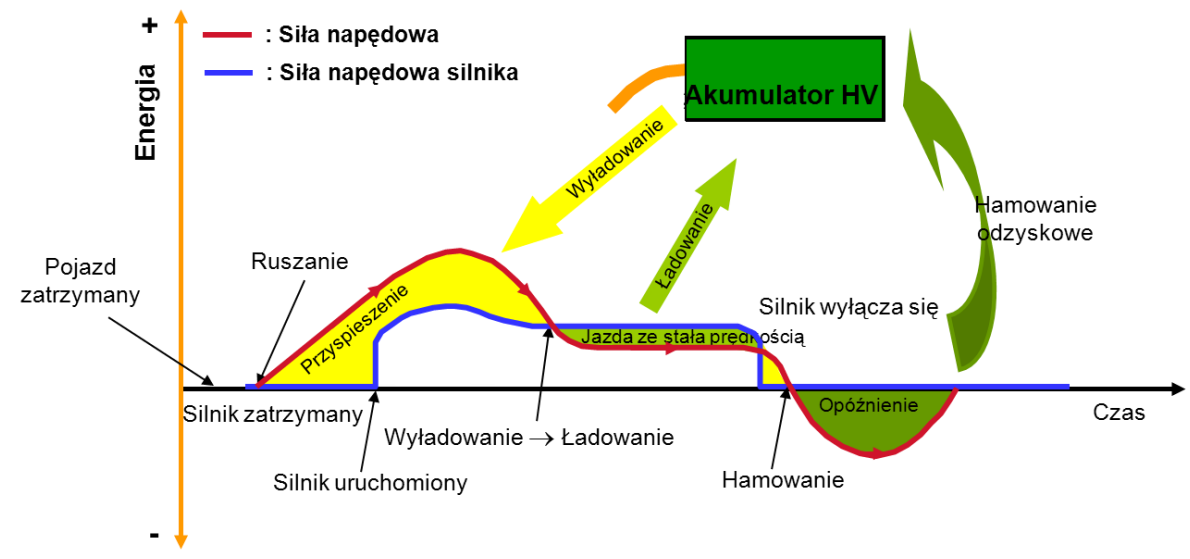

Rys. 4. Sposób wykorzystania energii w pojeździe hybrydowym[2]

Uzasadnieniem dla zastosowania napędu hybrydowego jest ruch miejski, w którym częste hamowania, postoje na skrzyżowaniach i jazda w korkach pozwalają na odzyskanie energii kinetycznej ruchu i optymalne wykorzystanie mocy silnika spalinowego. Takie rozwiązanie daje możliwość bardzo dużej, sięgającej nawet do ok. 50\%, oszczędności energii [10].

W pojazdach tego typu, w których silnik spalinowy współpracuje z silnikiem elektrycznym elektronicznie sterowany układu hamowania (ECB) rozdziela siłe hamowania pomiędzy hydrauliczny układ hamulcowy i hamowanie odzyskowe co zilustrowano graficznie na rysunku 5. Podział ten zależy od prędkości i czasu jazdy pojazdu. 
Influence of changes in electrical and electronic equipment on the increase... Wptyw zmian wprowadzonych $w$ wyposażeniu elektrycznym i elektronicznym...

Rozwiązanie problemu rekuperacji energii elektrycznej oparte na wykorzystaniu alternatora oraz superkondensatora zaproponował koncern Mazda w systemie i-ELOOP. Proces wytwarzania energii oraz ładowania superkondensatora ma miejsce po zwolnieniu pedału gazu w samochodzie, którego prędkość maleje. Odzyskana energia może służyć do zasilania urządzeń peryferyjnych pojazdu, takich jak klimatyzacja czy system audio. Według zapewnień producenta system i-ELOOP ma pozwolić na nawet 10\% oszczędność paliwa [5].

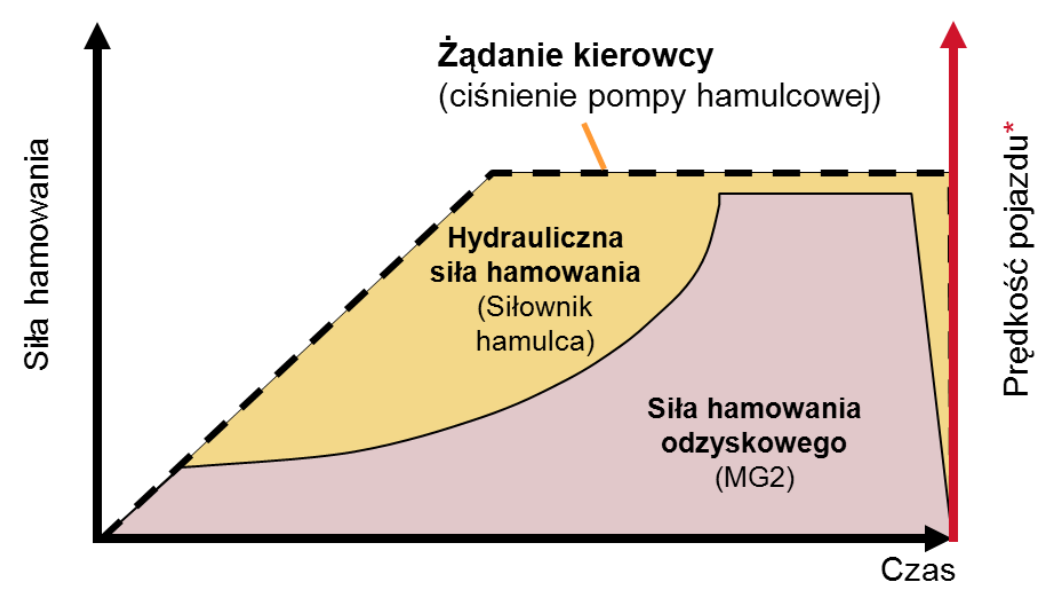

Rys. 5. Zmiany w rozdziale sity hamowania w uktadzie (ECB) [2]

Tradycyjne akumulatory kwasowo-ołowiowe nie mają możliwości przyjmowania dużych prądów podczas hamowania pojazdu bez znaczącego obniżenia ich żywotności natomiast superkondensatory są zdolne do przyjmowania i wydawania prądów o wartości do $800 \mathrm{~A}$ bez utraty trwałości. Superkondensatory mają zastosowanie tam gdzie potrzebny jest duży wydatek mocy w krótkim przedziale czasu oraz szybkie magazynowanie dużych ilości energii przy przepływie dużych wartości prądów [1].

Kolejny system oszczędzania energii oparty jest na tym, że energia kinetyczna przepływających spalin wykorzystywana jest do napędu turbogeneratora zlokalizowanego w układzie wydechowym silnika spalinowego. Wysoko obrotowy generator ma za zadanie wspomóc pracę alternatora oraz poprawić bilans energetyczny układu zasilania [5]. Turbogenerator ten współpracujący z silnikiem o zapłonie ZI o pojemności $2000 \mathrm{dm}^{3}$ jest wstanie wygenerować maksymalnie nawet $6 \mathrm{~kW}$ mocy [6]. Rozwiązanie takie może znaleźć zastosowanie w pojazdach hybrydowych jako element poprawiający bilans energii elektrycznej współpracujący z urządzeniami rekuperującymi energię z siły kinetycznej co ma wpływ na niezawodność tego układu.

Analizując bilans energetyczny obwodu oświetlenia można stwierdzić, że włączenie świateł mijania wiąże się z poborem mocy ok. $130 \mathrm{~W}$. 
Obecnie przepisy dopuszczają włączenie tylko świateł do jazdy dziennej (bez świateł pozycyjnych przednich i tylnych oraz oświetlenia tablicy rejestracyjnej). Zastosowanie dwóch świateł $\mathrm{z}$ diodami LED o mocy np. $5 \mathrm{~W}$ oznacza całkowity pobór mocy na poziomie $10 \mathrm{~W}$. Wynika $\mathrm{z}$ tego mniejsze nawet o 0,2 1/100 km zużycie paliwa co pomnożone przez ilość pojazdów na drogach, oznacza to ograniczenie emisji dwutlenku węgla do atmosfery [13].

Konwencjonalne źródła światła zastąpiono diodami LED także w obwodach lamp sygnałowych: świateł postojowych, pozycyjnych oraz kierunkowskazów uzyskując oszczędność zużycia energii, wzrost niezawodności i dodatkowo możliwość sterowania jasnością świecenia świateł hamowania w zależności od jego intensywności.

Obecnie coraz częściej stosowane są źródła typu LED w samochodowej technice świetlnej z uwagi na wielokrotnie dłuższą w porównaniu ze źródłami tradycyjnymi trwałość oraz energooszczędność. Ta sama funkcja oświetleniowa realizowana jest przy poborze dużo mniejszej mocy, np. światło pozycyjne z żarówką o mocy $10 \mathrm{~W}$ może być wykonane przy użyciu LED o mocy $1 \mathrm{~W}$ [4]. Istotne znaczenie, ze względu na czas reakcji kierowców ma także znacznie krótszy czas uzyskania pełnego strumienia świetlnego natychmiast po włączeniu zasilania, co np. wpływa na skrócenie drogi hamowania ze względu na szybszą reakcję użytkowników obserwujących te światła. Najważniejszą regulacją w Unii Europejskiej odnośnie świateł do jazdy dziennej jest Regulamin ECE R87 [9].

Niektórzy producenci pojazdów samochodowych biorą pod uwagę wykorzystanie energii słonecznej do zasilania wybranych urządzeń systemu komfortu. W rozwiązaniach tych uzyskuje się wydajność konwersji energii słonecznej przy $15 \%$ na $1 \mathrm{~m}^{2}$ powierzchni i izolacji termicznej wynoszącej $500 \mathrm{~W} / \mathrm{m}^{2}$ [3].

\section{Podsumowanie, Wnioski}

W artykule przedstawiono rozważania dotyczące wzrostu niezawodności pojazdów w wyniku wprowadzenia istotnych zmian strukturalnych w instalacji oraz funkcjonowaniu elektrycznego wyposażenia. W związku ze wzrostem ilości elementów i podzespołów o dużej konsumpcji mocy oraz pojawieniem się napędów hybrydowych i elektrycznych wzrosło zapotrzebowanie na energie elektryczną.

W wyniku tego obwód zasilania elektrycznego musi sprostać nowym wymaganiom dotyczącym także niezawodności, dlatego wdrożono układ zarządzania energią gdzie za pomocą komputera sterującego realizowana jest aktywna diagnoza akumulatora i kontrola obciążenia dla zagwarantowania dostatecznej energii do rozruchu silnika spalinowego.

Zintegrowany system zasilania i rozruchu zrealizowany $\mathrm{w}$ jednej maszynie elektrycznej prądnico-rozruszniku łączy dwie funkcje zasilania i rozruchu co wpływa na znaczące zwiększenie niezawodności tego systemu a praca $\mathrm{w}$ trybie start-stop szczególnie w uchu miejskim może zapewnić redukcję zużycia paliwa nawet o $20 \%$. 
Influence of changes in electrical and electronic equipment on the increase... Wplyw zmian wprowadzonych $w$ wyposażeniu elektrycznym i elektronicznym...

Daje to także znaczący aspekt ekologiczny w postaci redukcji emisji spalin oraz szybki i cichy rozruch silnika a także wzrost bezpieczeństwa i obniżenie kosztów eksploatacji.

Istotną cechą współczesnych napędów pojazdów elektrycznych jest możliwość odzysku energii w czasie hamowania gdzie efektywność rekuperacji jest w znacznym stopniu zależna od konfiguracji układu napędowego. Należy oczekiwać powszechnego wdrażania hamowania rekuperacyjnego ponieważ nowe możliwości akumulowania energii elektrycznej w superkondensatorach zwiększą jego efektywność. Ta zmiana sposobu napędzania samochodów prowadzi do znacznych oszczędności zużycia energii szczególnie przy jeździe w ruchu miejskim oszczędności te mogą sięgać nawet do $50 \%$.

Stosowanie $\mathrm{w}$ reflektorach świateł do jazdy dziennej źródeł typu LED wiąże się również ze znacznym zwiększeniem niezawodności i bezpieczeństwa ponieważ oświetlenie tego typu cechuje: długa żywotność, odporność na wstrząsy, mały pobór mocy, emitowanie ostrego i wyraźnego światła dobrze widzianego w dzień.

\section{Literatura}

[1] Fice M. Setlak R.: Napęd hybrydowy pojazdów miejskich z podwójnym zasobnikiem energii elektrycznej. Zeszyty Problemowe - Maszyny elektryczne Nr 79/2008, 138-144.

[2] Grudziński P.: System napędu hybrydowego Toyota. Akademia Toyoty Toyota Motor Poland.

[3] Herner A. Riehl H-J.: Elektrotechnika i elektronika w pojazdach samochodowych, WKŁ, Warszawa 2014.

[4] Kaźmierczak P.: Źródła LED w samochodowej technice świetlnej, Transport Samochodowy 2011, nr 4, 85-94.

[5] Luft M. Olszowiec P.: Analiza systemów podnoszących sprawność silników spalinowych, Logistyka 2012, nr 3, 1389-1393.

[6] Luft M. Olszowiec P.: Straty silnika spalinowego szansą na rekuperację energii elektrycznej, Logistyka 2011, nr 6, 2291-2299.

[7] Merkisz J. Pielecha I.: Układy elektryczne pojazdów hybrydowych, WPP, Poznań 2015,.

[8] Plich M.: Alternatywne źródła zasilania energią pojazdów samochodowych. Międzynarodowa Konferencja Naukowa Transport XXI Wieku. Warszawa 2004.

[9] Putz Ł.: Oświetlenie LED jako samochodowe światła do jazdy dziennej, Poznań University Of Technology Academic Journals, Electrical Engineering, No 83/2015, 221-228.

[10] Sosin Z.: Niekonwencjonalne napędzanie samochodów - sposób na obniżenie kosztów transportu i zmniejszenie zanieczyszczenia środowiska. Foton 102, Jesień 2008.

[11] Tutaj J.: Nowe rozwiązanie samochodowego prądnico-rozrusznika, Journal of KONES Internal Combustion Engines 2005, vol. 12, 335-342. 
[12] www.creeaza.com/tehnologie/electronica-electricitate/Masina-electricaspeciala-cu-r983.php (dostęp z dnia 15.10.2015).

[13] www.motofakty.pl/artykul/dzial-oswietlenie-diodowe-swiatla-do-jazdydziennej.html (dostęp z dnia 15.09.2015).

[14] Zeszyt do samodzielnego kształcenia nr 287, Audi A8' 03 - podzespoły elektryczne.

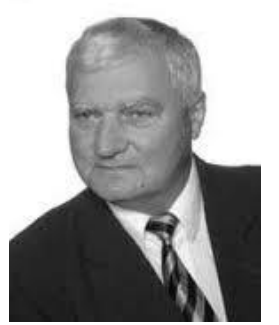

drinż Mieczystaw Plich pracuje w Zakladzie Systemów Informatycznych i Mechatronicznych w Transporcie na Wydziale Transportu Politechniki Warszawskiej. W swojej pracy naukowej zajmuje się głównie tematyka zwiazana z elektrycznym wyposażeniem pojazdów samochodowych. (Udział 34\%).

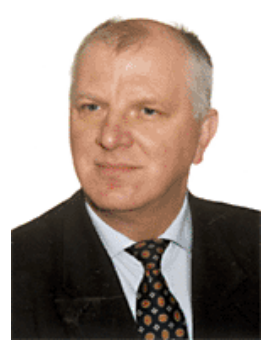

dr inz. M. Dziubiński pracuje $w$ Katedrze Pojazdów Samochodowych na Wydziale Mechanicznym Politechniki Lubelskiej. W swojej pracy naukowej zajmuje się diagnostyka, elektrotechnika i elektronika samochodowa. (Udziat 33\%).

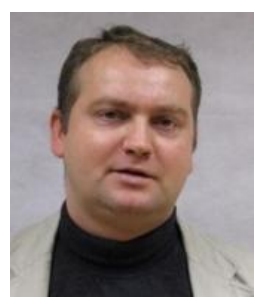

dr inż. Krzysztof Stypulkowski pracuje w Zaktadzie Systemów Informatycznych $i$ Mechatronicznych $w$ Transporcie na Wydziale Transportu Politechniki Warszawskiej. W swojej pracy naukowej zajmuje się głównie tematyka zwiazana $z$ elektrycznym wyposażeniem pojazdów, technikg świetlna $i$ termowizja w transporcie. (Udziat 33\%). 
Influence of changes in electrical and electronic equipment on the increase... Wplyw zmian wprowadzonych w wyposażeniu elektrycznym i elektronicznym... 